\title{
Influencing prolificacy of sows by selection for physiological factors
}

\author{
R. K. Johnson, D. R. Zimmerman, W. R. Lamberson* and S. Sasaki† \\ Animal Science Department, University of Nebraska, Lincoln. NE 68583, U.S.A.
}

\begin{abstract}
Summary. The potential to improve prolificacy, with major emphasis on selection for components of litter size, ovulation rate and prenatal survival, and selection for physiological factors are reviewed. Response to selection for physiological factors is superior to direct selection if physiological factors have moderate heritabilities and moderate to high genetic correlations with the trait to be improved. There are very few estimates of the genetic parameters needed to calculate the relative efficiency of direct and indirect selection. Testis size is highly heritable and positively correlated genetically with ovulation rate in both mice and pigs and may be potentially useful in an index with litter size to improve ovulation rate and prenatal survival. Selection for growth, ovulation rate or litter size has increased ovulation rate in mice, but the physiological explanations are different. Selection for litter size in a line of pigs previously selected for ovulation rate was effective; the realized heritability was $0 \cdot 18 \pm 0.06$. Potential improvements in litter size from index selection for ovulation rate and prenatal survival are discussed and compared to direct selection for litter size.
\end{abstract}

\section{Introduction}

Litter size is an important component of reproductive efficiency, and improvements in litter size will result in significant improvements in economic efficiency (Tess, Bennett \& Dickerson, 1983). Litter size is lowly heritable (about $10 \%$ ) and is controlled primarily by the genotype of the sow. Direct selection for litter size is based on the dam's records, which halves the effective heritability. The accuracy of estimating genetic merit for litter size in potential replacement boars and gilts is low. Even though the accuracy of selection is low, litter size is highly variable and expected rates of progress from direct selection are approximately $1.5 \%$ per year. In comparison, progress per year may be as high as $3-5 \%$ for highly heritable traits that are measured in both sexes.

The identification of physiological factors, measurable in either or both sexes, that may be used to enhance the rate of response from direct selection for litter size would be useful. Further, litter size is a natural index of the component traits of ovulation rate, fertilization rate and embryo and fetal survival rate. The weighting given to the components in direct selection may not be optimum.

Efforts to improve litter size using novel selection criteria should not overlook the potential from long-term, direct selection. Little will be said of the latter means of improvement in this paper because it is dealt with by other speakers at this conference. The potential to improve litter size by selection for physiological factors and by selection for the component traits will be considered in this paper.

\footnotetext{
- Present address: Department of Animal Science, University of Missouri, Columbia, MO 65211, U.S.A.

† Present address: Pig Improvement Company, Inc., Box 348, Franklin, KY 42134, U.S.A.
} 


\section{Efficiency of indirect selection}

Several alternatives exist for using indicator traits in selection programmes. The efficiency of indirect selection relative to direct selection depends on the sex and age, before or after mating, when both the trait of importance and the indicator trait can be measured. Walkley \& Smith (1980) compared direct selection for litter size with indirect selection for three different kinds of physiological trait. Physiological traits considered were male sex-limited (M, e.g. testis size), female sex-limited (F, e.g. ovulation rate) and traits measureable in both sexes (B, e.g. gonadotrophin concentration). They also calculated the expected response from combining each of these traits in a selection index with litter size. The results were calculated for sheep, but a range of parameters was used and the results can be generalized to pigs. The following assumptions were made: (1) physiological traits could be measured before breeding; (2) traits had heritabilities of 10 or $35 \%$, repeatabilities of 15 or $40 \%$, and genetic correlations of physiological traits with litter size were 0.3 or 0.7 and from 1 to 5 repeated records of the physiological traits could be made; (3) selection intensity was assumed to be $10 \%$ for males and $60 \%$ for females; (4) the number of paternal half-sibs of each sex was 20 , with an average of 10 per breeding female; and (5) response to direct selection for litter size assumed that selection was based on the records of the dam and her paternal half-sisters. The indexes for indirect selection use the individual and its half-sib family record.

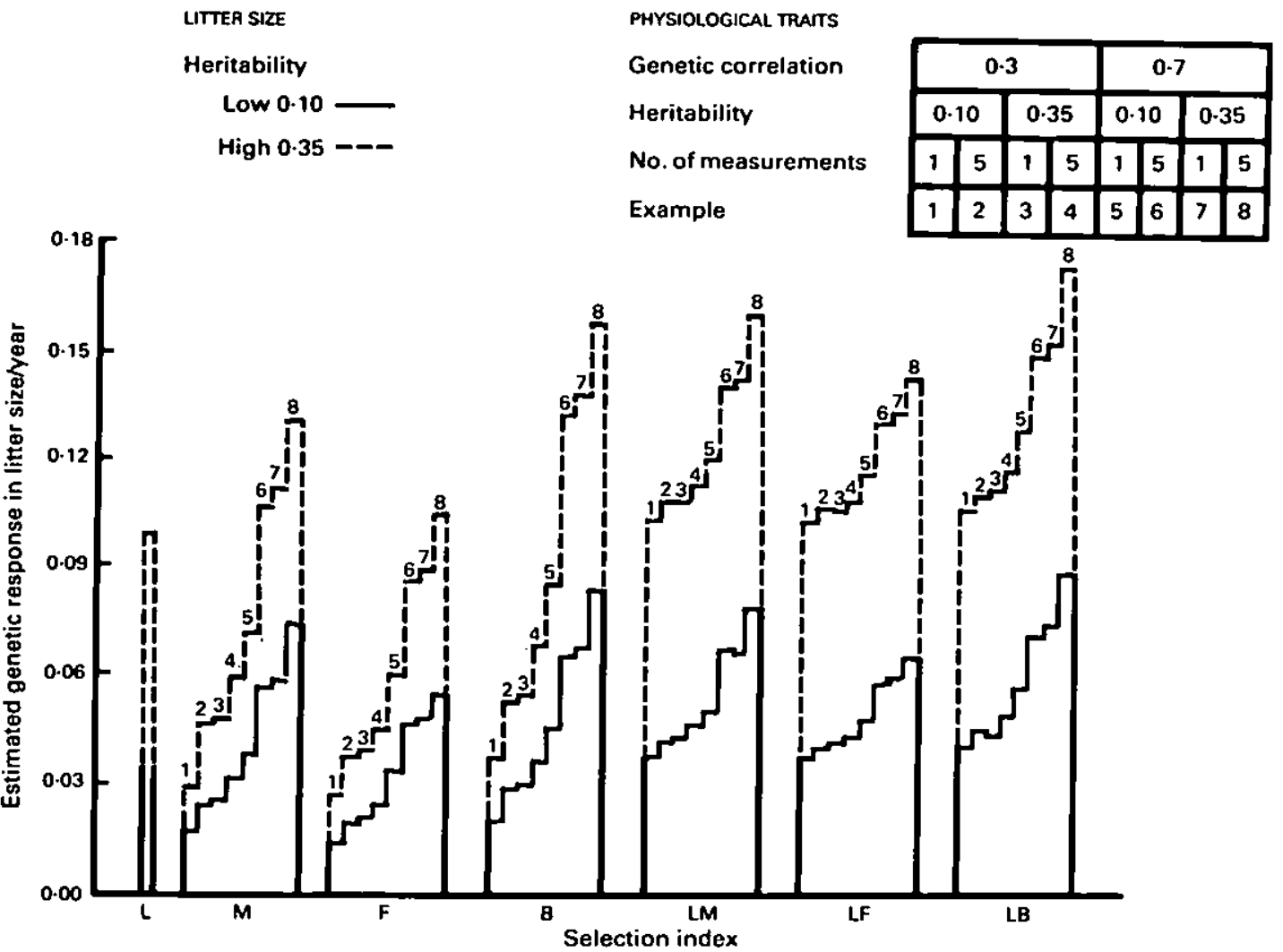

Fig. 1. Genetic responses from direct selection for litter size (L), from indirect selection through traits which are male sex-limited (M), female sex-limited $(F)$ or measured in both sexes (B), and from combined selection using these indirect traits in selection indices which include litter size. Results are presented for a range of parameter values of the different traits. (From Walkley \& Smith, 1980.) 
The results of the analysis are presented in Fig. 1. Combined selection always leads to greater expected response than direct selection. The response is most dependent on the genetic correlation between litter size and the physiological trait and the heritability of the physiological trait. Indirect selection is less efficient than direct selection unless the heritability of the physiological trait is high and its genetic correlation with litter size is high.

Traits to be improved may be measurable before mating in one sex, e.g. ovulation rate or age at puberty, but may be more difficult to measure than a physiological trait that is measurable before breeding in one or both sexes, e.g. testis size or gonadotrophin concentration. This was not considered by Walkley \& Smith (1980). Expected responses from both direct and indirect selection for such a trait were calculated and are summarized in Table 1 . The trait to be improved is designated $\mathrm{Y}$ and the indicator trait as $\mathrm{X}$. The response is shown as phenotypic standard deviations of $\mathrm{Y}$ per generation for the genetic parameters and criterion of selection described in the table.

Table 1. Expected genetic gain per generation for trait $Y$ in phenotypic standard deviations from direct selection for $\mathrm{Y}$, measurable pre-breeding in females only, indirect selection for $\mathrm{X}$, measurable pre-breeding in one or both sexes, and combined selection*

\begin{tabular}{|c|c|c|c|c|c|c|c|c|c|}
\hline \multicolumn{3}{|c|}{ Parameter values $\dagger$} & \multicolumn{7}{|c|}{ Criterion of selection $\ddagger$} \\
\hline$h_{Y}^{2}$ & $h_{x}^{2}$ & $r_{8}$ & 1 & 2 & 3 & 4 & 5 & 6 & 7 \\
\hline 0.1 & 0.1 & 0.3 & 0.058 & 0.073 & 0.154 & 0.048 & 0.089 & 0.060 & 0.091 \\
\hline 0.1 & 0.3 & 0.3 & 0.058 & 0.073 & 0.154 & 0.084 & 0.112 & 0.064 & 0.118 \\
\hline 0.3 & 0.1 & 0.3 & 0.174 & 0.220 & 0.431 & 0.084 & 0.227 & 0.175 & 0.229 \\
\hline 0.3 & $0 \cdot 3$ & 0.3 & 0.174 & 0.220 & 0.431 & 0.145 & 0.267 & 0.178 & 0.270 \\
\hline 0.1 & 0.1 & 0.7 & 0.058 & 0.073 & 0.154 & 0.113 & 0.130 & 0.069 & 0.141 \\
\hline 0.1 & $0 \cdot 3$ & 0.7 & 0.058 & 0.073 & 0.154 & 0.195 & 0.183 & 0.086 & 0.211 \\
\hline 0.3 & 0.1 & 0.7 & 0.174 & 0.220 & 0.431 & 0.195 & 0.299 & 0.181 & 0.306 \\
\hline 0.3 & 0.3 & 0.7 & 0.174 & $0 \cdot 220$ & 0.431 & 0.338 & 0.391 & 0.195 & 0.411 \\
\hline
\end{tabular}

- Selection intensities were $5 \%$ for males and $30 \%$ for females.

$\dagger h_{\mathrm{Y}}^{2} \mathrm{~h}_{\mathrm{X}}^{2}$ and $r_{\mathrm{g}}$ are the heritabilities of traits $\mathrm{X}$ and $\mathrm{Y}$ and the genetic correlation between them respectively.

$\$ 1=$ females only on $Y$.

$2=$ females on $Y$, males on dam's record for $Y$.

$3=$ females on $Y$, males on mean of four full-sibs for $Y$.

$4=$ females and males for $X$.

$5=$ females for $Y$ and males for $X$.

$6=$ females only for an index of $X$ and $Y$.

$7=$ females for an index of $X$ and $Y$, males for $X$.

These results indicate that direct selection for $\mathrm{Y}$ in females and sib selection for $\mathrm{Y}$ in males tends to be the most efficient method of selection. Selection for an indicator trait in both sexes is less effective than direct selection when the genetic correlation of the indicator trait with the trait to be improved is low, but selection for physiological traits can result in substantial increases in the rates of response if the traits are moderately to highly heritable and are highly correlated with traits to be improved. One might consider selection for a physiological trait that is easier to measure than the trait to be improved and if the expected rate of response to indirect selection is similar to direct selection. Combined selection makes use of all the information and is the most effective method.

\section{Genetic parameters for physiological factors}

There are very few estimates of the heritabilities of physiological factors in pigs, or of the genetic correlation of these factors with litter size or its component traits. Estimates of these parameters are necessary before the relative efficiency of direct and indirect selection for specific physiological factors can be calculated. 
Hereditary variation has been reported in gonadotrophin concentrations (Bartke, 1979) and in ovarian responsiveness to gonadotrophins (Durrant, Eisen \& Ulberg, 1980; Spearow \& Bradford, 1983; Spearow, 1984). Most of the evidence comes from line or breed differences in mice, rats and sheep. In laboratory species, the line differences were the result of selection for either natural or induced ovulation rate or for litter size, while the breeds of sheep studied differed naturally for ovulation rate and litter size.

Spearow (1984) reported that $65 \%$ of the variation in hormone-induced ovulation rate was between lines and that this difference was controlled by $3-5$ genes. The response in immature mice ranged from 8.8 to 53.6 eggs. Further, he postulated that the success of attempts to increase ovulation rate by selecting for increased serum gonadotrophins would depend on the ovarian response characteristics of the population. Spearow (1984) found genetic variation among lines in follicle number, ovarian LH receptors and in ovarian responsiveness due to elevated production of 3',5'-cyclic adenosine monophosphate in response to hCG. Spearow \& Bradford (1983) reported that both selection for body weight and litter size resulted in increased ovulation rate, but the physiological explanations for the responses were different.

These studies show that the combinations of natural and artificial selection and genetic drift caused by isolation of populations has resulted in differences between lines in the hormonal systems that regulate the reproductive traits. It does not necessarily follow that selection for various measures of the hormonal control systems, e.g. serum gonadotrophins, number of receptors or measures of ovarian or testicular steroidogenesis and the feedback regulation of gonadotrophins, will produce predictable changes in the reproductive traits. However, many measures of the biochemical and physiological controls of ovarian and testicular function can be measured in both sexes and can be measured before breeding age. They are potentially useful in selection programmes, but the nature and the magnitude of the genetic variation must be understood. Precise estimates of heritabilities and genetic correlations require measurements of large populations and will be difficult, but important, to obtain before the relative efficiency of indirect selection can be evaluated.

The same gonadotrophic hormones regulate reproductive activity in both sexes (Land \& Carr, 1979). Land (1973) found that testis size and ovulation rate were correlated genetically in both mice and sheep. This stimulated several investigations into possible genetic variation in gonadotrophic hormones and their relationship to reproduction. Male and female mice from a line selected for high induced ovulation rate had increased gonadal sensitivity to follicle-stimulating hormone (Wolfe et al., 1981) and ewes and rams of the Finnish Landrace breed were less sensitive to negative feedback of steroids and had earlier pubertal releases of luteinizing hormone than did those of less prolific breeds (Land \& Carr, 1975; Land \& Lee, 1976).

This research has prompted investigations into the possible use of selection for testis size in boars to alter reproductive performance in females. Heritabilities of intact testis size and excised testis weight of boars have been estimated to be 0.58 and 0.77 , respectively (Legault, Gruand \& Oulion, 1980). Toelle, Johnson \& Robison (1984) found heritabilities for testis length, width and volume at 140 days to be between 0.16 and 0.25 , and heritabilities of measurements at 168 days ranged from 0.16 to 0.36 . Young, Leymaster \& Lunstra (1984) found that heritabilities of testis measurements ranged between 0.12 and 0.78 . Schinckel, Johnson \& Kittock (1984) selected boars at birth for high and low predicted genetic merit for testis weight at 140 days. Prediction was based on records of the sire, sire of the dam and two full sibs of the dam. A heritability of 0.5 was assumed and differences between the high and low group for observed testis weight at 140 days of age agreed very closely with the predicted difference. For mice, Mafizul Islam, Hill \& Land (1976) found a realized heritability of 0.52 and Williams (1984) reported a realized within-family heritability of 0.48 for testis weight.

Few precise estimates of the genetic correlations between testis size and components of prolificacy are available. Mafizul Islam et al. (1976) reported genetic correlations of testis weight and ovulation rate in mice to be 0.50 and 0.25 in primiparous and nulliparous females, respectively, but 
correlated responses in litter size at birth were not significant. Selection for litter size in mice, however, has resulted in lines that differ significantly in testis weight (Joakimsen \& Baker, 1977; Eisen \& Johnson, 1981). Eisen \& Johnson (1981) reported that the partial genetic correlation holding body weight constant between litter size and testis weight was 0.42 .

Few estimates of the genetic correlation between testis size and reproduction traits are available for pigs. Schinckel, Johnson, Pumfrey \& Zimmerman (1983) reported that 9 generations of selection for ovulation rate resulted in boars with $9-15 \%$ heavier testes from 120 to 183 days of age than boars from a randomly selected control line. Correlations of testis weights with litter size and ovulation rate tended to be positive, but were not large.

Schinckel et al. (1984) found that levels of hormones were different for boars that were selected for high and low testis size. A rise in LH concentration occurred at approximately 100 days of age and boars with large testis size had significantly higher and more variable concentrations of $\mathrm{LH}$ than did boars with low testis size. They also had higher maximum concentrations of LH during the pubertal rise and these concentrations tended to reach maximum levels at younger ages. Concentrations of FSH did not differ between the groups. Concentrations of testosterone increased linearly with age and tended to be higher for boars with high testis size. Levels of oestradiol-17 $\beta$ changed little from 42 to 84 days of age, but increased steadily thereafter. Boars with large testis size had a more rapid increase than did boars with low testis size. However, concentrations of both testosterone and oestradiol- $17 \beta$ were similar for boars in both groups after adjusting for testis size.

These data indicate that boars selected for large testis size were less sensitive to the negative feedback of gonadal steroids or that the testes were more sensitive to a given level of gonadotrophins. It is not clear whether selection for testis size will alter female reproductivity. Studies with mice, in which there was genetic selection for ovulation rate, have attributed changes in ovulation rate to changes in circulating FSH concentrations or to changes in ovarian sensitivity to FSH (Bindon \& Pennycuick, 1974; Wolfe et al., 1981). Eisen \& Johnson (1981) found that lines of mice that differed in litter size and ovulation rate differed in testis size, but did not differ in concentrations of testosterone.

\section{Selection for components of litter size}

Several workers have successfully selected for litter size in mice (e.g. Joakimsen \& Baker, 1977; Eisen, 1978; Bakker, Wallinga \& Politiek, 1978; Bradford, 1979). Similar selection in pigs, however, was unsuccessful (Ollivier \& Bolet, 1981). Litter size is determined by ovulation rate, fertilization rate and embryo and fetal mortality. Selection for litter size in mice has resulted in increased ovulation rate (Falconer, 1960; Joakimsen \& Baker, 1977; Bakker et al., 1978; Bradford, 1979). Selection for ovulation rate was successful in mice (Bradford, 1969; Land \& Falconer, 1969), but produced little increase in litter size until selection was relaxed (Bradford, 1979). Mice selected for high ovulation rate have high ovulation rate and high embryo/fetal mortality compared to unselected control lines.

Selection for ovulation rate in the Nebraska Gene Pool population of pigs gave a response similar to that observed for mice (for a summary see Johnson, Zimmerman \& Kittock, 1984). Selection was effective (Fig. 2), but resulted in little change in numbers born per litter (Fig. 3).

The number of litters per line averaged about 40 from generations 0 to 9 and from generations 11 to 16 . There were 89 control and 76 select-line litters in generation 10 . The regressions of line means for litter size at birth on generation were not significant during the generations of selection for ovulation rate (generations 0-9), but were significant for generations 10 to 16 of relaxed selection, although the regression of the difference between the select and control line on generation was not significant.

The difference between lines in litter size at birth was 1.3 piglets in generation 9 , the last generation that gilts selected for ovulation rate were farrowed, and averaged $0.70 \pm 0.22$ (s.e.m.) 


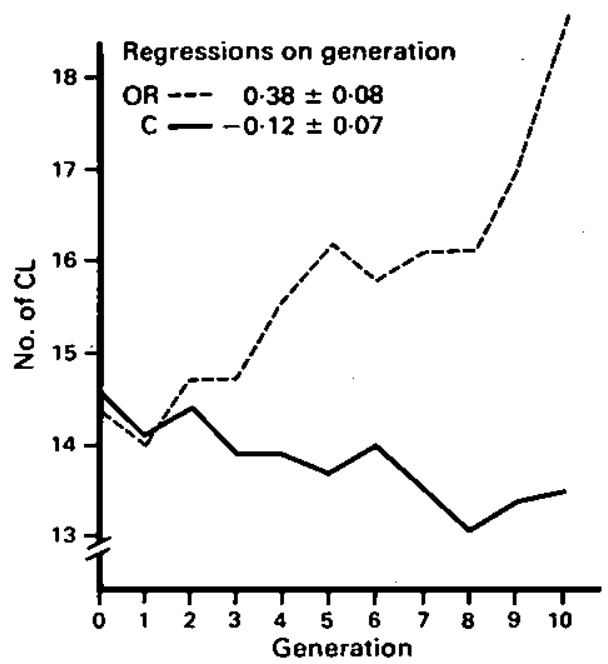

Fig. 2. Regresions of selected (OR) and control (C) line means for number of corpora lutea on generation number in pigs. (From Johnson et al., 1984.)

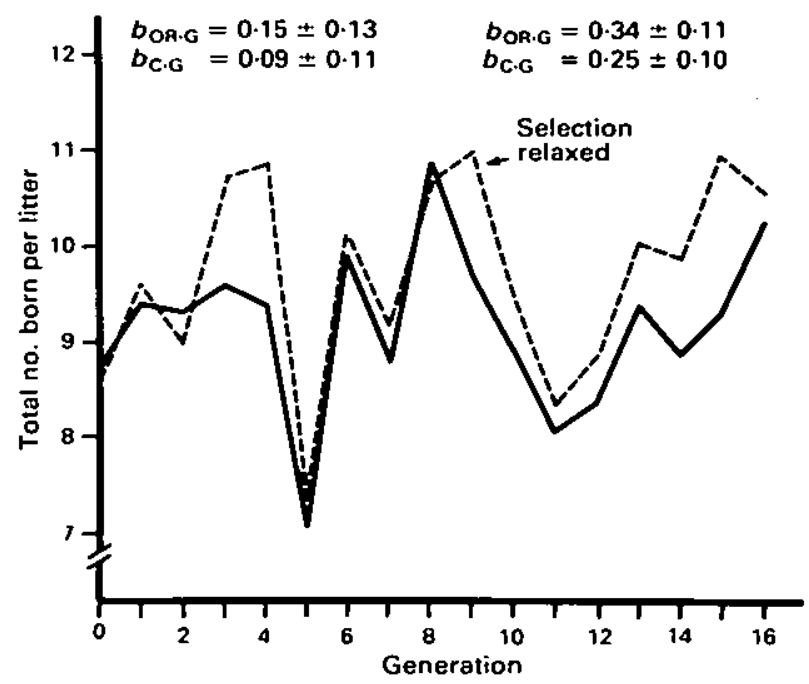

Fig. 3. Response in litter size of pigs at birth, and regression coefficients $(b)$ on generation number (G), during selection for ovulation rate (generations 0-9; from Johnson et al., 1984) and during relaxed selection (generations 10-16; R. K. Johnson, unpublished) in pigs. ---Selected line (OR); - control line (C).

piglets during generations 10 to 16 of relaxed selection. From generations 11 to 15 of relaxed selection it appeared that the difference between the select and control line was increasing; however, the difference between lines in generation 16 was only 0.3 piglets.

Nine generations of selection for ovulation rate has increased litter size by about 0.7 piglets per litter. There does not appear to have been any natural selection for embryo survival during the generations of relaxed selection. This is different from the result observed for mice in which litter size increased significantly during relaxed selection in the line selected for ovulation rate (Bradford, 1979). Previous analyses (Johnson et al., 1984) have also found that advancing parity does not 
result in increased litter size at birth in the high ovulating line. The mean ( \pm s.e.m.) difference between the select and control lines from generations 10 to 13 was $0.37 \pm 0.39$ piglets for parity 2 and $0.84 \pm 0.52$ piglets for parity 3 .

At this point it is not clear whether ovulation rate has declined in the high ovulating line during the period of relaxed selection. The difference between the lines was 3.7 corpora lutea in generation 9 , the generation from which the lines were sampled to populate for the subsequent selection lines. Ovulation rate at third or later oestrus was measured after two generations of relaxed selection in pure and cross-line females and the difference between lines was found to be 1.9 corpora lutea (Johnson, Pumfrey, Jones \& Zimmerman, 1981). Lamberson (1984), however, evaluated ovulation rate at second oestrus in generation 15 and found the difference between the lines to be 3.9 corpora lutea. He also found the difference between the lines in number of embryos at 30 days of gestation to be 2.7 embryos. This agrees with earlier experiments conducted with 9 th and 10 th generation gilts and sows that found differences between the lines to be between 3.4 and 5 corpora lutea and that embryo/fetal survival was about 5\% less to Day 30 of gestation and $10 \%$ less to 70 days of gestation for the select line (Johnson et al., 1984).

It has been proposed by Rigor, Meyer, First \& Casida (1963), and Land \& Falconer (1969), that genetic differences in ovulation rate are mediated via differences in endogenous gonadotrophin concentrations and/or differences in ovarian sensitivity to given levels of gonadotrophins. Ogata (1979) administered three dose levels of PMSG to gilts of each line and found a similar response in both ovulation rate and concentrations of steroids, indicating that ovarian sensitivity appears to be similar in the lines selected for ovulation rate. He also harvested granulosa cells from preovulatory follicles, treated them with pig LH and assayed for LH receptors. The lines had similiar numbers of LH receptors per granulosa cell and a similar affinity constant for $\mathrm{LH}$. There does not appear, therefore, to be a difference between lines in ovarian sensitivity.

A recent evaluation indicated that the select line had a longer inter-oestrous interval (21.9 vs 20.4 days) than the control line and that the left ovary was responsible for most of the advantage in ovulation rate, 10.3 vs 7.4 corpora lutea (Kelly, Kopf \& Zimmerman, 1985). However, characterization of the populations of follicles on various days of the oestrous cycle failed to provide a basis for the line difference in ovulation rate. Therefore, experiments conducted to date have not provided a physiological explanation for the genetic difference in ovulation rate.

Females born in generation 10 in the line selected for high ovulation rate were assigned randomly within litter to Line AP, selected for decreased age at puberty, Line LS, selected for increased number of fully formed piglets per litter, and Line RS, selected randomly. The ovulation rate control line $(\mathrm{CL})$ was maintained contemporaneously with random selection.

The regressions of line means on generation are shown in Fig. 4. All lines increased significantly from generation 0 , which corresponds to generation 10 in Fig. 3, to generation 6 . The response to 6 generations of selection for litter size was evaluated by regressing the difference between Lines LS and RS from generations $1-6$ on both generation number and on difference in cumulative selection differential. The regression of line difference (LS-RS) on generation number was $0.16 \pm 0.05$ pigs and the regression of line difference on difference in cumulative selection differential, shown in Fig. 5 , was $0.09 \pm 0.03$ pigs. The standard errors of these regression coefficients are not adjusted for genetic drift. The realized heritability is $0.18 \pm 0.06$; selection for litter size in a line previously selected for ovulation rate was effective.

\section{Selection for components of litter size}

Ovulation rate in pigs is highly heritable and responds to selection. However, increased ovulation rate was accompanied by a decrease in embryo/fetal survival rate of $1.6 \%$ per generation so that the increase in litter size at birth was only $20-30 \%$ of the increase in ovulation rate. It therefore appears 


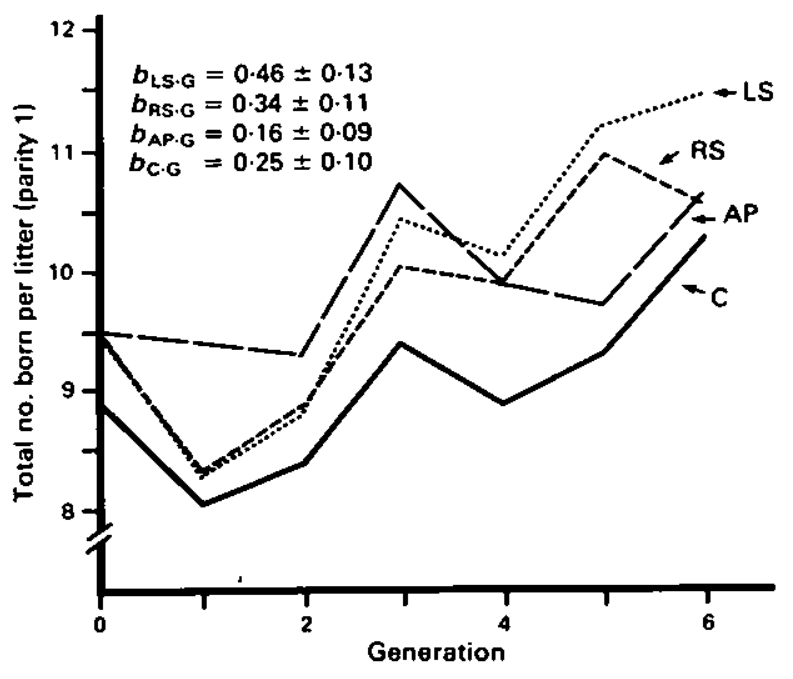

Fig. 4. Response in litter size of pigs at birth, and regression coefficients $(b)$ on generation number (G), litter size (LS) or decreased age at puberty (AP) in the high ovulation rate line. Line RS (high ovulation rate, relaxed selection) and the control line $(C)$ were selected randomly (R. K. Johnson, unpublished).

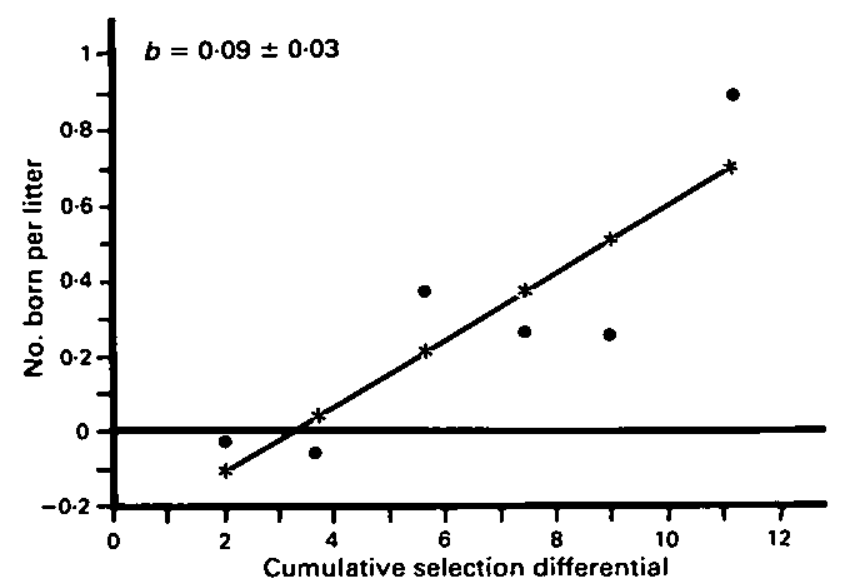

Fig. 5. Regression of the difference between lines LS and RS on the difference in cumulative selection differential of pigs (R. K. Johnson, unpublished).

that more rapid improvement in litter size could be made if ovulation rate and embryo/fetal survival could be improved simultaneously.

Litter size is a natural index of ovulation rate and prenatal survival. However, the natural index may not give optimum weight to the components. The optimum weighting depends on the population means for both ovulation rate and prenatal survival.

Several workers have investigated the relationship between ovulation rate, prenatal survival and litter size. For a review of earlier work see Wrathall (1971). Three recent experiments with relatively large numbers of observations are summarized in Figs 6 and 7. Blichfeldt \& Almlid (1982) found a curvilinear relationship between number of embryos at Day 30 of gestation and ovulation rate in gilts. The maximum number of embryos occurred at 18.1 ovulations. However, King \& 


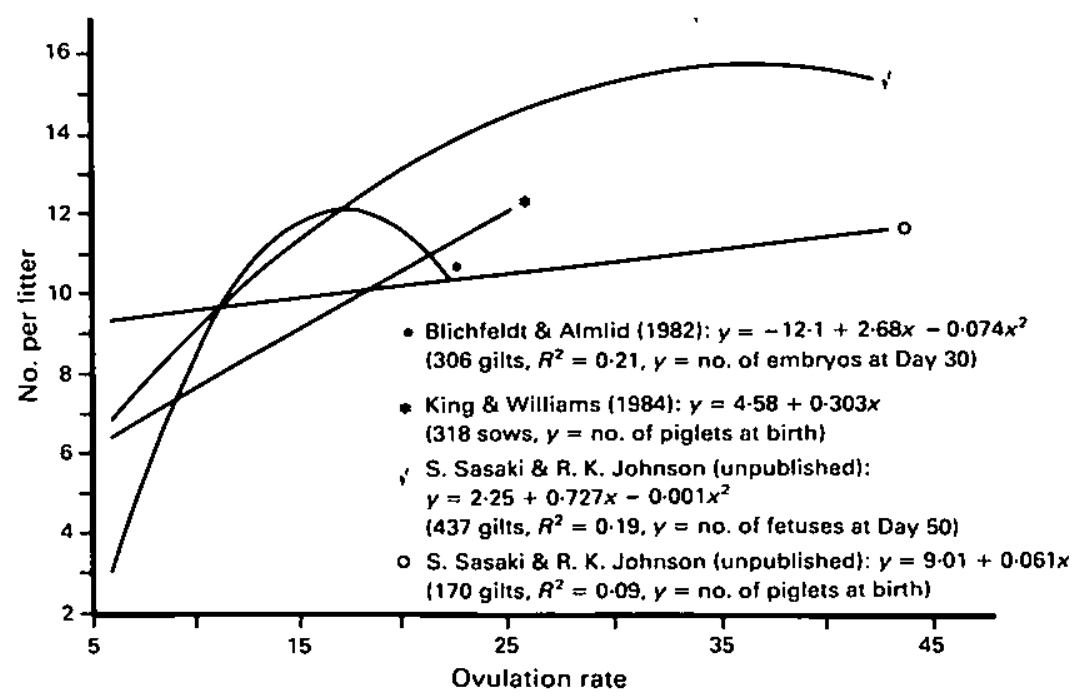

Fig. 6. Relationships between number per litter during gestation or at term and ovulation rate of pigs.

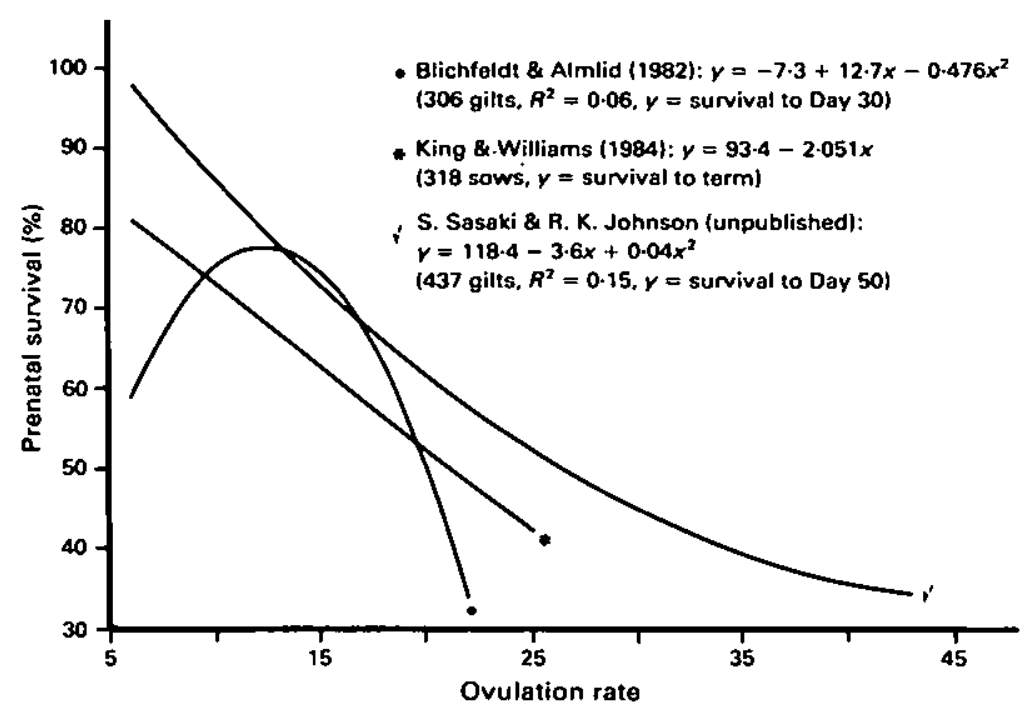

Fig. 7. Relationships between prenatal survival and ovulation rate of pigs.

Williams (1984) measured ovulation rate by laparoscopy in sows and found a linear relationship between number of live piglets per litter and litter size. Ovulation rate and number of fetuses at 50 days of gestation have a curvilinear relationship (S. Sasaki \& R. K. Johnson, unpublished). The gilts were ranked on an index of ovulation rate and prenatal survival to 50 days of gestation and the high-ranking gilts were farrowed. In these gilts, the relationship between litter size and ovulation rate was linear (Fig. 6).

The relationships between prenatal survival and ovulation rate found by these same workers are reported in Fig. 7. King \& Williams (1984) reported a linear relationship while Blichfeldt \& Almlid (1982) found a highly significant quadratic relationship. The maximum survival of $78 \%$ occurred in 
gilts having 13.4 ovulations. The low prenatal survival in gilts with below average ovulation rates is somewhat surprising. In our experiment (S. Sasaki \& R. K. Johnson, unpublished) the relationship was curvilinear $(P<0.07)$, but was essentially linear when 4 gilts with ovulation rates from 25 to 43 were deleted from the data.

When ovulation rate is high relative to prenatal survival, litter size is correlated more highly with prenatal survival than with ovulation rate. Selection for litter size in such a population would probably place more selection pressure on prenatal survival, and if heritable, it would respond to selection and litter size would improve. Ovulation rate and prenatal survival are negatively correlated and some decrease in ovulation rate might be expected. On the other hand, selection for litter size in a population with low or average ovulation rate and high prenatal survival would put more selection pressure on ovulation rate relative to that on prenatal survival. The response might be similar to direct selection for ovulation rate. In fact, ovulation rate did increase in the line selected for litter size (Ollivier \& Bolet, 1981). Selection pressure during selection for litter size in the high ovulation rate line in our experiment was probably directed more toward prenatal survival than to litter size.

Table 2. Estimates of parameters and expected response per generation in litter size from three selection criteria

\begin{tabular}{|c|c|c|c|c|}
\hline \multirow[b]{2}{*}{ Trait } & \multicolumn{3}{|c|}{ Estimates of parameters } & \multirow{2}{*}{$\begin{array}{l}\text { Expected response } \\
\text { in litter size (pigs) }\end{array}$} \\
\hline & $\mu$ & $\sigma$ & $h^{2}$ & \\
\hline $\begin{array}{l}\text { Ovulation rate (OR) } \\
\text { Prenatal survival (PS) } \\
\text { Litter size (LS) }\end{array}$ & $\begin{array}{c}14 \\
0 \cdot 73 \\
10 \cdot 2\end{array}$ & $\begin{array}{l}2 \cdot 6 \\
0 \cdot 19 \\
2 \cdot 5\end{array}$ & $\begin{array}{l}0.45 \\
0.15 \\
0.10\end{array}$ & \\
\hline \multicolumn{5}{|c|}{ Selection criteria } \\
\hline \multicolumn{4}{|c|}{$\begin{array}{l}\text { Litter size at birth, intensity }=0.95 \\
\text { Number of fetuses at } 50 \text { days of gestation, intensity }=1.65 \\
\text { Index of OR and PS at } 50 \text { days of gestation, intensity }=1.65\end{array}$} & $\begin{array}{l}0.12 \\
0.19 \\
0 \cdot 29\end{array}$ \\
\hline
\end{tabular}

Johnson et al. (1984) have developed an index of ovulation rate and prenatal survival and describe a selection scheme that is expected to increase litter size faster than direct selection for litter size. Estimates of parameters were calculated from the results of selection for ovulation rate in the Nebraska Gene Pool population. These estimates, and the expected responses in litter size to three selection schemes, are presented in Table 2.

All the selection schemes produce 40 litters by 15 sires per generation. Method $\mathbf{l}$ is direct selection for litter size while in Methods 2 and 3, all daughters (about 160) are mated, laparotomy is performed at 50 days of gestation, and selection is either for number of fetuses (Method 2) or an index of ovulation rate and prenatal survival (Method 3).

The increase in expected response from Methods 1 to 2 is due to higher selection intensity in dams of breeder males (15/160 vs 15/40) while the increase in expected response from Methods 2 to 3 is due to optimum emphasis on the components of litter size. The relative emphasis on ovulation rate and prenatal survival was calculated to be $42: 58 \%$ in the natural index (direct selection for litter size) and $68: 32 \%$ in the optimum index. Theoretical expectations are that selection on the optimum index will increase ovulation rate without the corresponding decrease in prenatal survival that occurred from direct selection for litter size. 


\section{References}

Bakker, H., Waltinga, J.H. \& Politiek, R.D. (1978) Reproduction and body weight of mice after longterm selection for large litter size. J. Anim. Sci. 46, I 572-1580.

Bartke, A. (1979) Genetic models in the study of anterior pituitary hormones. In Genetic Variation in Hormone Systems, pp. 113-126. Ed. J. G. M. Shire. CRC Press, New York.

Bindon, B.M. \& Pennycuik, P.R. (1974) Differences in ovarian sensitivity of mice selected for fecundity. $J$. Reprod. Fert. 36, 221-224.

Blichfeldt, T. \& Almlid, T. (1982) The relationship between ovulation rate and embryonic survival in gilts. Theriogenology 21, 677-680.

Bradford, G.E. (1969) Genetic control of ovulation rate and embryo survival in mice. I. Response to selection. Genetics, Princeton 61, 905-921.

Bradford, G.E. (1979) Genetic variation in prenatal survival and litter size. XII. Biennial Symposium on Animal Reproduction. J. Anim. Sci. 49 (Suppl. 2), 66-74.

Durrant, B.S., Eisen, E.J. \& Ulberg, L.C. (1980) Ovulation rate, embryo survival and ovarian sensitivity to gonadotrophins in mice selected for litter size and body weight. J. Reprod. Fert. 59, 529-537.

Eisen, E.J. (1978) Single-trait and antagonistic index selection for litter size and body weight in mice. Genetics, Princeton 88, 781-811.

Eisen, E.J. \& Johnson, B.H. (1981) Correlated responses in male reproductive traits in mice selected for litter size and body weight. Genetics, Princeton 99, $513-524$.

Falconer, D.S. (1960) The genetics of litter size in mice. $J$. cell. comp. Physiol. 56 (Suppl. 1), 153, Abstr.

Joakimsen, O. \& Baker, R.L. (1977) Selection for litter size in mice. Acta agric. scand. 27, 301-318.

Johnson, R.K., Pumfrey, R.A., Jones, A.P.K. \& Zimmerman, D.R. (1981) Embryo and fetal loss in gilts differing in ovulation rate. J. Anim. Sci. 53 (Suppl. 1), 74, Abstr.

Johnson, R.K., Zimmerman, D.R. \& Kittock, R.J. (1984) Selection for components of reproduction in swine. Livestock Prod. Sci. 11, 541-558.

Kelly, C.R., Kopf, J.D. \& Zimmerman, D.R. (1985) Evaluation of differences in follicle populations between high ovulating select and control line gilts during different stages of the estrous cycle. J. Anim. Sci. 61, Suppl. 1, Abstr.

King, R.H. \& Williams, 1.H. (1984) The influence of ovulation rate on subsequent litter size in sows. Theriogenology 21, 677-680.

Lamberson, W.R. (1984) Selecsion for reproductive traits in swine. Ph.D. dissertation, University of Nebraska, Lincoln.

Land, R.B. (1973) The expression of female sex-limited characters in the male. Nature, Lond. 241, 208-209.

Land, R.B. \& Carr, W.R. (1975) Testis growth and plasma LH concentration following hemicastration and its relationship with female prolificacy in sheep. J. Reprod. Fert. 45, 495-501.

Land, R.B. \& Carr, W.R. (1979) Reproduction in domestic animals. In Genetic Variation in Hormone Systems, pp. 89-112. Ed. J. G. M. Shire. CRC Press, New York
Land, R.B. \& Falconer, D.S. (1969) Genetic studies of ovulation rate in the mouse. Genet. Res. 13, 25-46.

Land, R.B. \& Lee, C.J. (1976) Testis growth, a possible genetic predictor of female reproductivity. Anim. Prod. 22, 135, Abstr.

Legault, C., Gruand, J. \& Oulion, L.F. (1980) Development and genetic value of an in vivo method of estimating testis weight in young boars. Anim. Breed. Abstr. 48, 26, Abstr.

Mafizul Islam, A.B.M., Hill, W.G. \& Land, R.B. (1976) Ovulation rate of lines of mice selected for testis weight. Genet. Res. 27, 23-32.

Ogata, Y. (1979) Physiological characterization of ovulation rate in swine selected for high owulation rate. M.S. thesis, University of Nebraska, Lincoln.

Ollivier, L. \& Bolet, G. (I981) Selection for prolificacy in the pig: results of a 10 generation selection cxperiment. Journées Rech. Porcine en France 13, pp. 26I-268.

Rigor, E.M., Meyer, R.K., First, N.L. \& Casida, L.E. (1963) Endocrine differences associated with follicular development and ovulation rate in swine due to breed and energy intake. J. Anim. Sci. 22, 43-50.

Schinckel, A., Johnson, R.K., Pumfrey, R.A. \& Zimmerman, D.R. (1983) Testicular growth in boars of different genetic lines and its relationship to reproductive performance. $J$. Anim. Sci. 56, $1065-1076$.

Schinckel, A.P., Johnson, R.K. \& Kittock, R.J. (1984) Testicular development and endocrine characteristics for boars selected for either high or low testis size. $J$. Anim. Sci. 58, 675-685.

Spearow, J.L. (1984) The mechanism of action of genes controlling gonadal function. Proc. $10 \mathrm{~h} \mathrm{~h} \mathrm{mt}$. Congr. Anim. Reprod. \& A. I.. Urbana vol. 4, pp. VI9-VI16.

Spearow, J.L. \& Bradford, G.E. (1983) Genetic variation in spontaneous ovulation rate and $\mathrm{LH}$ receptor induction in mice. J. Reprod. Fert. 69, 529-537.

Tess, M.W., Bennett, G.L. \& Dickerson, G.E. (1983) Simulation of genetic changes in life cycle efficiency of pork production. II. Effects of components on efficiency. J. Anim. Sci. 56, 354-368.

Toelle, V.D., Johnson, B.H. \& Robison, O.W. (1984) Genetic parameters for testes traits in swine. J. Anim. Sci. 59, 967-973.

Walkley, J.R.W. \& Smith, C. (1980) The use of physiological traits in genetic selection for litter size in sheep. J. Reprod. Fert. 59, 83-88.

Williams, J.C. (1984) Infiuence of selection for body weight and testis weight on the growth of mice. Ph.D. dissertation, University of Edinburgh.

Wolfe, H.G., Bartke, A., Amador, A., Van Sickle, M., Dalterio, S. \& Brown, D. (1981) Testicular function in strains of mice selected for differences in gonadotrophin-induced ovulation. J. Endocr. 90, 367-373.

Wrathall, A.E. (1971) Prenatal survival in pigs. Part 1. Ovulation rate and its influence on prenatal survival and litter size in pigs. Commonwealth Agricultural Bureaux, Farnham Royal, England.

Young, L.D., Leymaster, K.A. \& Lunstra, D.D. (1984) Breed means and genetic parameters for testicular traits in swine. Proc. 10th Int. Congr. Anim. Reprod. \& A. I., Urbana, vol. I, p. 536, Abstr. 